\title{
IAMJ
}

INTERNATIONAL

AYURVEDIC

MEDICAL JOURNAL

Case Report

ISSN: 23205091

Impact Factor: 5.344

\section{MANAGEMENT OF FEMALE INFERTILITY DUE TO TUBAL BLOCKAGE BY AYURVEDIC TREATMENT PROTOCOL: A CASE REPORT}

\author{
Amisha H. Dholariya ${ }^{1}$, L. P. Dei ${ }^{2}$, S. B. Donga ${ }^{3}$ \\ ${ }^{1} \mathrm{PG}$ Scholar, ${ }^{2} \mathrm{HOD} \&$ Professor, ${ }^{3}$ Professor, \\ Dept. of Prasutitantra \& Streeroga, IPGT \& RA, Jamnagar, Gujarat, India
}

Corresponding Author: amisha94d@gmail.com

https://doi.org/10.46607/iamj3708112020

(Published online: November 2020)

Open Access

(C) International Ayurvedic Medical Journal, India 2020

Article Received: 20/10/2020 - Peer Reviewed: 06/11/2020 - Accepted for Publication: 08/11/2020

(D) Check for updates

\begin{abstract}
Motherhood is one of those transforming experience which can't quite put into words. Infertility represents a major crisis for most couples, with both partners experiencing loss in ways that affect them as individuals, as family members and as members of society as a whole. Tubal factor is second major cause of female infertility. In Tubal factor, modern management are dependent on Tubal Surgery or IVF or Embryo Transfer. All these methods are the solution only for the anatomical aspect of the tube and no success in establishing the tubal function. The present case report revealed effect of Virechana and Uttarbasti karma in a known case of secondary infertility due to Fallopian Tube Blockage. Virechana is indicated in Vandhyatva and Yonivyapada chikitsa. Uttarabasti is a very important and unique Ayurvedic procedure, which is mentioned for the genito-urinary problems. Successful conception occurs after this treatment.
\end{abstract}

Keywords: Ayurveda, Infertility, Vandhyatwa, Fallopian Tube Blockage, Virechana, Uttarbasti

\section{INTRODUCTION}

Vandhyatwa is not a disease but a revelation of an underlying disease. According to Ayurveda Vandhyatwa is not only inability to conceive but not begetting a live progeny. In Ayurveda lots of importance given to progeny because they are source of Pleasure, Strength, happiness, worth, potency, vastness, fame, utility, satisfaction, etc. In case of Vandhyatva human is devoid of all these. Because of that our Acharyas had given 
importance to healthy progeny. Infertility is defined as a failure to conceive within one or more years of regular unprotected coitus. ${ }^{1}$ Tubal factor is second major cause of female infertility i.e. $25-35 \%{ }^{2}$ In Tubal factor, modern management are dependent on Tubal Surgery or IVF or Embryo Transfer. Tubal Surgery depends on the site of blockage like Salpingo-ovariolysis, proximal tubal cannulation, Fimbrioplasty/ Fimbriolysis, Neosalpingostomy, Reversal of tubal ligation etc. Overall success rate is as follows: Salpingo- ovariolysis $65 \%$, Tubocornual anastomosis 55\%, Fimbrioplasty 32\%, Tubotubal anastomosis $75 \% .{ }^{3}$ IVF and ET are offered to women in whom tuboplasty has failed or to women with extensive and irreparable tubal damage. The overall success rate of $20 \%-30 \%$ is obtained. ${ }^{4}$ The adverse effects are anaesthetic complications, wound infection, failure of surgery and high incidence of ectopic pregnancy. Ayurveda has a great scope in this field. So, today's need is to develop a safe and cost effective Ayurvedic protocol for this sensitive problem.

\section{Case Report}

A 28 years female patient attended at OPD of PTSR Dept., IPGT \& RA, Jamnagar with complain of secondary infertility for 2 years. She had active marriage life of 4 years. She was conceived before 2 years with ectopic pregnancy in right side. So, in right fallopian tube salpingectomy was done. After that couple was trying for conception but failed. After all necessary examination patient was advised for USG, which was found normal. On the basis of past history, she was advised for HSG, in which free spillage was not found from both the tubes. So, patient was advised for treatment for fallopian tube blockage.

\section{Treatment Protocol}

$1^{\text {st }}$ month: Virechana Karma: After menstruation (from $5^{\text {th }}$ day of menstruation)

\begin{tabular}{|c|c|c|c|}
\hline No. & Procedure & Drug \& Dose & Duration \\
\hline 1 & Deepana, Pachana & Trikatu churna 2 gm / 3 times with warm water & 3 Days \\
\hline 2 & Snehapana & $\begin{array}{l}\text { Go ghrita (as per Koshta and Agni) } 30 \mathrm{ml}-150 \mathrm{ml} \text { (Increasing } 30 \mathrm{ml} \\
\text { each day) }\end{array}$ & 5 Days \\
\hline 3 & Abhyanga \& Swedana & Bala Taila (Sida cordifolia)- 1 time in a day, bashpa swedana & Days \\
\hline 4 & $\begin{array}{l}\text { Abhyanga, Swedana, } \\
\text { Virechana Karma }\end{array}$ & Trivrutta Avaleha - $80 \mathrm{gm}$ & 1 Day \\
\hline 5 & Sansarjana Karma & Diet & 5 Days \\
\hline
\end{tabular}

$2^{\text {nd }}$ month: Uttarbasti Karma: After menstruation (from $5^{\text {th }}$ day of menstruation)

\begin{tabular}{|c|c|c|c|c|}
\hline $\begin{array}{l}\text { Steps of } \\
\text { I.U.U.B. }\end{array}$ & $\begin{array}{l}\text { Drug } \\
\text { Administered }\end{array}$ & Dose & $\begin{array}{l}\text { Dura- } \\
\text { tion }\end{array}$ & $\begin{array}{l}\text { Total duration } \\
\text { of therapy }\end{array}$ \\
\hline I. & $\begin{array}{l}\text { Apamarga } \\
\text { Kshara Taila }\end{array}$ & $\begin{array}{l}\text { After menstruation }{ }^{5} \text {, } \\
3 \text { to } 5 \mathrm{ml} \text { Apamarga Kshara Taila was administered in form } \\
\text { of intra uterine Uttarabasti (IUUB) once in a day }\end{array}$ & 3 days & \multirow{2}{*}{$\begin{array}{l}\text { Two } \\
\text { Consecutive } \\
\text { cycles }\end{array}$} \\
\hline II. & $\begin{array}{l}\text { Phalakalyana } \\
\text { Ghrita }\end{array}$ & $\begin{array}{l}3 \text { to } 5 \mathrm{ml} \text { Phalakalyana Ghrita was administered in form of } \\
\text { intra uterine Uttara basti (IUUB) once in a day after } 3 \text { days } \\
\text { of completing the IUUB with Apamarga Kshara Taila }\end{array}$ & 3 days & \\
\hline
\end{tabular}

Pathya-Apathya (Do \& Don'ts): $\quad$ Yoga (Paschimottanasana, Bhujangasana, etc.), Pranayama, meditation, avoid intercourse during Uttarabasti procedure, avoid spicy, fried food, fast food, fermented food, overeating, suppression of natural urges, day sleep \& night awaking.
Result: After these 3 months treatment patient was advised for HSG, in which left fallopian tube was found open. Patient was conceived in next cycle and delivered healthy female child weighing $2.8 \mathrm{~kg}$ through LSCS. 


\section{DISCUSSION}

Artavavaha Srotasa can be considered as a broad term for both the functional units, i.e. Artava Beeja Vaha Srotasa and Artava Raja Vaha Srotasa ${ }^{6}$. The Artava Beeja Vaha Srotasa is Fallopian Tube, which is responsible to carry the Beeja Roopi Artava or ovum. All the three Doshas are responsible for tubal blockage \& infertility. But the role of Vata has certainly an edge over the other two. Also, the role of other Dosha can't be overlooked in inflicting tubal blockage. Kapha has Avarodhaka property which leads to occlusion of tubal lumen. This clarifies the relation of Kapha with tubal block especially when it is more structural than functional. Samshodhana therapy is the best for the vitiated Dosha Nirharana and correction of Agni. To remove obstruction and regularize the normal function of Vata Adhobhagadosaharana Virechana can prove beneficial. ${ }^{7}$ Uttarabasti is a minor operative Ayurvedic procedure, which can be carried out in different ways relying upon the purpose to achieve. By considering all the description given in classics, it looks to be a local as well as systemic (parenteral) route of administration to inject the medicine directly on the target organs. As it is already stated in disease review, that tubal blockage has been considered as the Tridoshaja condition dominantly Vata-Kapha Dosha. The drug which has properties of Vatakaphashamaka \& Tridoshaghna assumed as effective to open the fallopian tube. And also, local administration of any drug containing Sukshma, Laghu, Sara, Vyavayi, Vikasi, Pramathi, Lekhana etc. Guna, Katu Vipaka \& Ushna Virya can be assumed to have some effective role in removing tubal blockage. Apamarga-Kshara works in removal of blockage with its Lekhana properties. For Ropana and re-establish the function of fallopian tube there is need of medicated Ghee (Ghrita) like Phalakalyana Ghrita.

\section{CONCLUSION}

Fallopian tubes can be included under the heading of Artava Vaha Srotasa and Fallopian Tube blockage may be correlated with Artava Vaha Srotodushti/ Kshetradushti which is essential for conception. Tubal blockage can be the consequence of various gynaecological disorders like: Yonivyapad, Artavadushti, Asrigdara and Upadamsha. In modern the major cause of infertility related to tube is prior PID, TB, Abortion, D \& C / $\mathrm{D} \&$ E. Virechana helps in reducing menstrual abnormality. Uttarabasti of Apamarga Kshara Taila removes the blockage by its Lekhana Property and Uttarabasti of Phalakalyana Ghrita re-establish the function of tube by its Ropana property. So, Uttarabasti of trial drug is a safe, reliable \& efficacious measure in management of tubal infertility.

\section{REFERENCES}

1. DC Dutta, Textbook of Gynaecology including contraception, Jaypee, the health science publisher, $7^{\text {th }}$ edition, Hiralal Konar, page no. 186

2. DC Dutta, Textbook of Gynaecology including contraception, Jaypee, the health science publisher, $7^{\text {th }}$ edition, Hiralal Konar, Page no. 188

3. DC Dutta, Textbook of Gynaecology including contraception, Jaypee, the health science publisher, $7^{\text {th }}$ edition, Hiralal Konar, Page no. 202

4. Sunesh Kumar editor, V. G. Padubidri \& Shirish N. Daftary Emeritus editor, SHAW'S Textbook of Gynaecology, Elsevier, $17^{\text {th }}$ edition, Pg-219

5. Vaidya Yadavji Trikamji Acharya editor-Charaka Samhita of Agnivesha with Ayurvedadeepikavyakhya by Chakrapanidatta, ed. Chaukhambha Surbharati Prakashan, Varanasi, 2019, Siddhi Sthana-9/62-page no. 720

6. Dr. D. B. Ghanekar, Ayurveda Rahasya, Dipika Vyakhya Su. Shar., Meharchand Lakshman Das Publication, 13th edition, 1998, pg. 243-244

7. Pt. Hari Sadasiva Sastri Paradakara, Ashtangahrdaya of Vagbhata, Sarvangsundara commentary by Arundatta, Chaukhamba Sanskrit Sansthan, Varanasi, Reprint 2016, Chikitsa Sthana 4/8, P.603

\section{Source of Support: Nil \\ Conflict of Interest: None Declared}

How to cite this URL: Amisha H. Dholariya et al: Management Of Female Infertility Due To Tubal Blockage By Ayurvedic Treatment Protocol: A Case Report. International Ayurvedic Medical Journal \{online\} 2020 \{cited November, 2020\} Available from: http:/www.iamj.in/posts/images/upload/5181 5184.pdf 